\title{
Finger-nose test
}

Tiny Nair, MD, DM, FACC, FRCP(E)

Neurolog ${ }^{\circledR}$ 2018;91:230. doi:10.1212/WNL.0000000000005904

Somewhere between my finger and her nose,

She failed, she lost her track.

The diagnostic algorithm kicked in.

Strapped to the cold MRI table

She was sucked into the dark cavern.

Bottomless pit

Light at the end of the tunnel?

In bursts of 2-T magnet, hydrogen ions fall in line The scanner whirred around Looking for signs of indiscipline.

The T2-weighted white matter lit up in black

Revealing the rogue mass.

Verdict: doubtful resectability

But optimism blurs chasms of risk.

Scalp-flap, burr hole, crimson blood flood,

Mosquitos catch the bleeders;

Vampires of plastic tube suck blood.

The tumor is scooped out

The stench of cautery masks the sigh of relief.

Comforting hiss of the ventilator

Regular blip of the ECG monitor

Quiet ripple of the oximeter waves

But her pupils fail to react.

I wish she had not failed the finger-nose test.
Correspondence

Dr. Nair

tinynair@gmail.com

\section{MORE ONLINE}

\section{ค Audio}

Listen to Dr. Nair read this poem.

NPub.org/06lfs 1 


\section{Neurology}

Finger-nose test

Tiny Nair

Neurology 2018;91;230

DOI 10.1212/WNL.0000000000005904

\section{This information is current as of July 30, 2018}

\section{Updated Information \&} Services

\section{Subspecialty Collections}

\section{Permissions \& Licensing}

\section{Reprints}

including high resolution figures, can be found at: http://n.neurology.org/content/91/5/230.full

This article, along with others on similar topics, appears in the following collection(s):

\section{Coma}

http://n.neurology.org/cgi/collection/coma

MRI

http://n.neurology.org/cgi/collection/mri

Pupils

http://n.neurology.org/cgi/collection/pupils

Information about reproducing this article in parts (figures,tables) or in its entirety can be found online at:

http://www.neurology.org/about/about_the_journal\#permissions

Information about ordering reprints can be found online: http://n.neurology.org/subscribers/advertise

Neurology ${ }^{\circledR}$ is the official journal of the American Academy of Neurology. Published continuously since 1951, it is now a weekly with 48 issues per year. Copyright (O 2018 American Academy of Neurology. All rights reserved. Print ISSN: 0028-3878. Online ISSN: 1526-632X.

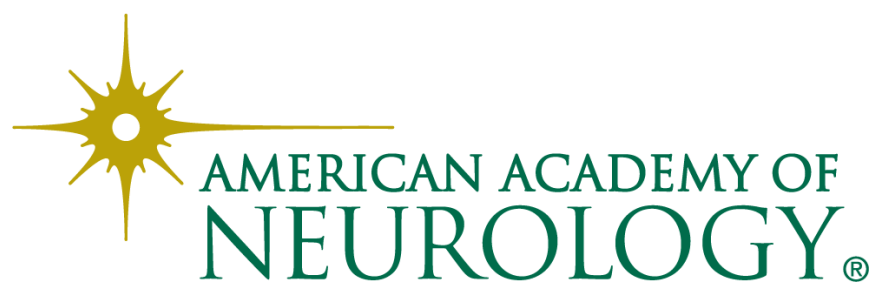

